\title{
Thrips species diversity in urban green spaces of Hangzhou (Zhejiang Province), China
}

\author{
M. Mirab-balou, ${ }^{1}$ X.L. Tong, ${ }^{2}$ X.X. Chen ${ }^{3}$ \\ ${ }^{1}$ Department of Plant Protection, College of Agriculture, Ilam University, Iran; ${ }^{2}$ Department of \\ Entomology, South China Agricultural University, Guangzhou, China; ${ }^{3}$ Institute of Insect Sciences, \\ Zhejiang University, Hangzhou, China
}

\begin{abstract}
Research was conducted on the fauna of Thysanoptera in the urban green spaces of Hangzhou, Zhejiang Province, China, during 20082012. The thrips were collected in different plant communities (mainly in parks) in the city. A total of 26 species from 19 genera in three different families were collected, among them Scolothrips latipennis Priesner, which is newly recorded for the fauna of China. New distribution records of seven species in China are reported. Results of the research indicate that the fauna of thrips of green areas of Hangzhou was quite abundant and diversified, and the occurrence of Selenothrips, Scirtothrips, Thrips, Frankliniella and Haplothrips species seems diverse and should be investigated further.
\end{abstract}

\section{Introduction}

The urban environment is a complex of habitats developed by humans from natural sites or agricultural land. Houses, villages, towns, cities, buildings, roads, and other features that characterize the urban environment have gradually and irreversibly changed the land-

Correspondence: Xue-Xin Chen, Institute of Insect Sciences, Zhejiang University, 866 Yuhangtang Road, Hangzhou 310058, China.

E-mail: xxchen@zju.edu.cn

Key words: thrips, park vegetation, predator, Hangzhou, China.

Acknowledgements: we are grateful to Prof. Zhang Wei-qiu of South China Agricultural University for his useful advice and to the anonymous reviewers for their useful comments.

Received for publication: 15 July 2013.

Revision received: 30 March 2014.

Accepted for publication: 1 April 2014.

(ㄷ) Copyright M. Mirab-balou et al., 2014

Licensee PAGEPress, Italy

Journal of Entomological and Acarological Research 2014; 46:1828

doi:10.4081/jear.2014.1828

This article is distributed under the terms of the Creative Commons Attribution Noncommercial License (by-nc 3.0) which permits any noncommercial use, distribution, and reproduction in any medium, provided the original author(s) and source are credited. scape of natural and agricultural areas. As a part of this change, some habitats and their associated plant and animal communities have been eliminated, while others have been expanded and new ones created. Many of the new habitats were intentional - parks, waterways, street trees, turfgrass, food stores - but some were incidental; e.g., standing water in roadside ditches, garbage and landfill sites near residential neighborhoods, and the underground sewer and storm drain networks in urban and suburban areas. These all provide habitats for a select group of insects and other arthropods, some of which have attained pest status (Robinson, 2005). Vegetation plays a key role in urban environments by providing food, breeding sites and shelter for animals and plants, and also by modifying the microclimate. Local conditions, climate, and available resources determine the distribution of some arthropods in the urban environment, and the abundance of some species is limited. Other species are broadly adapted to the resources and harborages in and around buildings, and these are cosmopolitan in their distribution and pest status (Rudd et al., 2002).

Thrips constitute the order Thysanoptera, of which there are presently over 6000 known species. The order is divided into two suborders, Tubulifera and Terebrantia. Tubulifera contains a single family, the Phlaeothripidae, whereas there are eight recognized families in the Terebrantia (Mound \& Morris, 2007; Mirab-balou et al., 2011a). Thysanoptera comprise an order of minute insects of considerable scientific and economic importance. Their habits range from forest and grasslands, to gardens and crops. Members of many species are fungivorous, phytophagous or carnivorous, or are gall-makers or inquilines, and some are vectors of viral and bacterial diseases of plants, or pollinators of flowers (Lewis, 1973; Mound, 1997). A large number of thrips species are considered pests, because they feed on plants of commercial value. Almost all species of pest thrips (>90\%) are in the Terebrantia family Thripidae; i.e., Thrips tabaci, Frankliniella occidentalis, Scirtothrips dorsalis, and Thrips palmi (Moritz et al., 2004; Mound, 2005). Only a few species of Phlaeothripidae are considered to be pests. These include Gynaikothrips ficorum (Marchal) and Gynaikothrips uzeli (Zimmerman) as pests of Ficus, and Haplothrips spp., which include pests of grains in Europe and central Asia (Reitz et al., 2011). Thrips in the genera Frankliniella (flower thrips) and Thrips also spread plant diseases through the transmission of viruses, such as Tospoviruses, Tomato Spotted Wilt Virus, and the Impatiens Necrotic Spot Viruses (Lewis, 1973; Mirab-balou \& Chen, 2011; Mound, 2005; Tong \& Lv, 2013).

In China, about 566 species of thrips have been recorded (Mirabbalou et al., 2011a), but a few of them, i.e., Frankliniella occidentalis (Pergande), Scirtothrips dorsalis Hood, Thrips palmi Karny, and Thrips tabaci Lindeman, are known as serious pests in this country (Reitz et al., 2011; Mirab-balou et al., 2012a, 2013).

Up to the present, only a few works have been conducted on thrips species associated with the urban environment. For example, 
Thysanoptera in the city of Lublin, Poland (Kucharczyk \& Seczkowska, 1990; Czepiel, 2004) or a few common species of thrips in the globally urban environment were mentioned by Robinson (2005). In China, data concerning the species composition, ecological connections and the number of thrips in urban areas are scarce; the present research is the first attempt to document the biodiversity of thrips species in the urban green spaces of Hangzhou, China.

\section{Materials and methods}

\section{Area of research}

Hangzhou is the largest city of Zhejiang Province, and is located in northern Zhejiang Province, eastern China, at the southern end of the Grand Canal of China, on the plain of the mid-lower reaches of the Yangtze River. The prefecture-level region of Hangzhou extends west to the border with the hilly Anhui Province, and east to the flatland near Hangzhou Bay. The city center is built around the eastern and northern sides of West Lake (Xihu), just north of the Qiantang River. Hangzhou's climate is humid subtropical with four distinctive seasons, characterised by long, very hot, humid summers and short, chilly, cloudy dry winters (with occasional snow).

\section{Collection of specimens}

To establish the occurrence of Thysanoptera species associated with urban green spaces of Hangzhou, different sites (i.e., parks, street trees, turfgrass, etc.) (Figure 1A-D) were randomly sampled from 2008-2012. Thrips collection methods included sweep net, aspirator, and shaking plants into a white dish; all specimens were preserved in $70 \%$ ethanol.

\section{Preparation of material for identification}

All collected material was macerated in $5 \% \mathrm{KOH}$ and subjected to dehydration in an ethanol series before being mounted onto glass slides in Hoyer's medium [see Mirab-balou and Chen (2010), for details on slide mounting]. All descriptions, measurements and photos were made with a Leica DM IRB microscope, and a Leica MZ APO microscope with a Leica Image 1000 system.

\section{Identification of slide-mounted specimens}

Slide-mounted specimens were identified using published keys (Reyes, 1994; Han, 1997; zur Strassen, 2003; Moritz et al., 2004; Masumoto, 2010). Species identity was confirmed by comparison with identified slide-mounted material held at the Institute of Insect Sciences, Zhejiang University, Hangzhou, China (ZJUH); the Insect Collection of Department of Entomology, South China Agricultural University (SCAU); Entomological Museum, Northwest A. \& F. University, Yangling, Shaanxi Province, China (NWAFU); and National Zoological Museum of China, Institute of Zoology, Chinese Academy of Sciences, Beijing, China (IOZ).

\section{Depository for thrips specimens}

The specimens are deposited in the Institute of Insect Sciences, Zhejiang University, Hangzhou, China (ZJUH).

\section{Results}

Among the 26 species listed in Table 1, some are graminicolous: Anaphothrips obscurus, Anaphothrips sudanensis and Chirothrips manicatus; these species are also common in China; most of them are

Table 1. Thrips species associated with urban green spaces of Hangzhou (Zhejiang Province).

\begin{tabular}{|c|c|c|c|}
\hline Family & Sub-family & Species & Thrips-associated plants \\
\hline Aeolothripidae & - & Aeolothrips fasciatus (Linnaeus) ${ }^{*}$ & Different plants infested with mites and thrips \\
\hline Thripidae & Dendrothripinae & Dendrothrips ornatus (Jablonowski) ${ }^{*}$ & Ligustrum sp., Rhododendron simsii \\
\hline Thripidae & Panchaetothripinae & Heliothrips haemorrhoidalis (Bouche) ${ }^{*}$ & Feeding on the leaves of a very wide range of trees and shrubs \\
\hline Thripidae & Panchaetothripinae & Selenothrips rubrocinctus (Giard) & Viburnum odoratissimum, Rhododendron simsii \\
\hline Thripidae & Sericothripinae & Sericothrips houji (Chou \& Feng) & Clover \\
\hline Thripidae & Thripinae & Anaphothrips obscurus Müller & Grasses \\
\hline Thripidae & Thripinae & Anaphothrips sudanensis Trybom & Grasses \\
\hline Thripidae & Thripinae & Chaetanaphothrips orchidii (Moulton) ${ }^{*}$ & Fatsia japonica \\
\hline Thripidae & Thripinae & Chirothrips manicatus (Haliday) ${ }^{*}$ & Grasses \\
\hline Thripidae & Thripinae & Frankliniella intonsa (Trybom) & Highly polyphagous; flowers of different plants \\
\hline Thripidae & Thripinae & Lefroyothrips lefroyi (Bagnall) & Camellia sinensis \\
\hline Thripidae & Thripinae & Megalurothrips distalis (Karny) & Ophiopogon japonicus; on flowers of plants family Fabaceae \\
\hline Thripidae & Thripinae & Microcephalothrips abdominalis (Crawford) & Various Asteraceae \\
\hline Thripidae & Thripinae & Mycterothrips glycines (Okamoto) & Glycine max, Alnus japonica \\
\hline Thripidae & Thripinae & Scirtothrips dorsalis Hood & Highly polyphagous \\
\hline Thripidae & Thripinae & Scolothrips latipennis Priesner ${ }^{* *}$ & Thuja sp. infested with mites \\
\hline Thripidae & Thripinae & Scolothrips takahashii Priesner & Thuja sp. infested with mites \\
\hline Thripidae & Thripinae & Taeniothrips eucharii (Whetzel) & Ophiopogon japonicus \\
\hline Thripidae & Thripinae & Thrips flavus Schrank & Highly polyphagous \\
\hline Thripidae & Thripinae & Thrips hawailensis (Morgan) & Highly polyphagous \\
\hline Thripidae & Thripinae & Thrips palmi Karny & Highly polyphagous \\
\hline Thripidae & Thripinae & Thrips tabaci Lindeman & Highly polyphagous \\
\hline Phlaeothripidae & Phlaeothripinae & Bagnalliella yuccae (Hind) & Yucca flower \\
\hline Phlaeothripidae & Phlaeothripinae & Gynaikothrips ficorum (Marchal) $^{*}$ & Ficus trees \\
\hline Phlaeothripidae & Phlaeothripinae & Haplothrips (Haplothrips) ganglbaueri Schmutz & Grasses \\
\hline Phlaeothripidae & Phlaeothripinae & Haplothrips (Haplothrips) reuteri (Karny)* & Flowers of various Asteraceae \\
\hline
\end{tabular}

*Newly recorded from the Zhejiang Province; ${ }^{* *}$ newly recorded for fauna of China. 

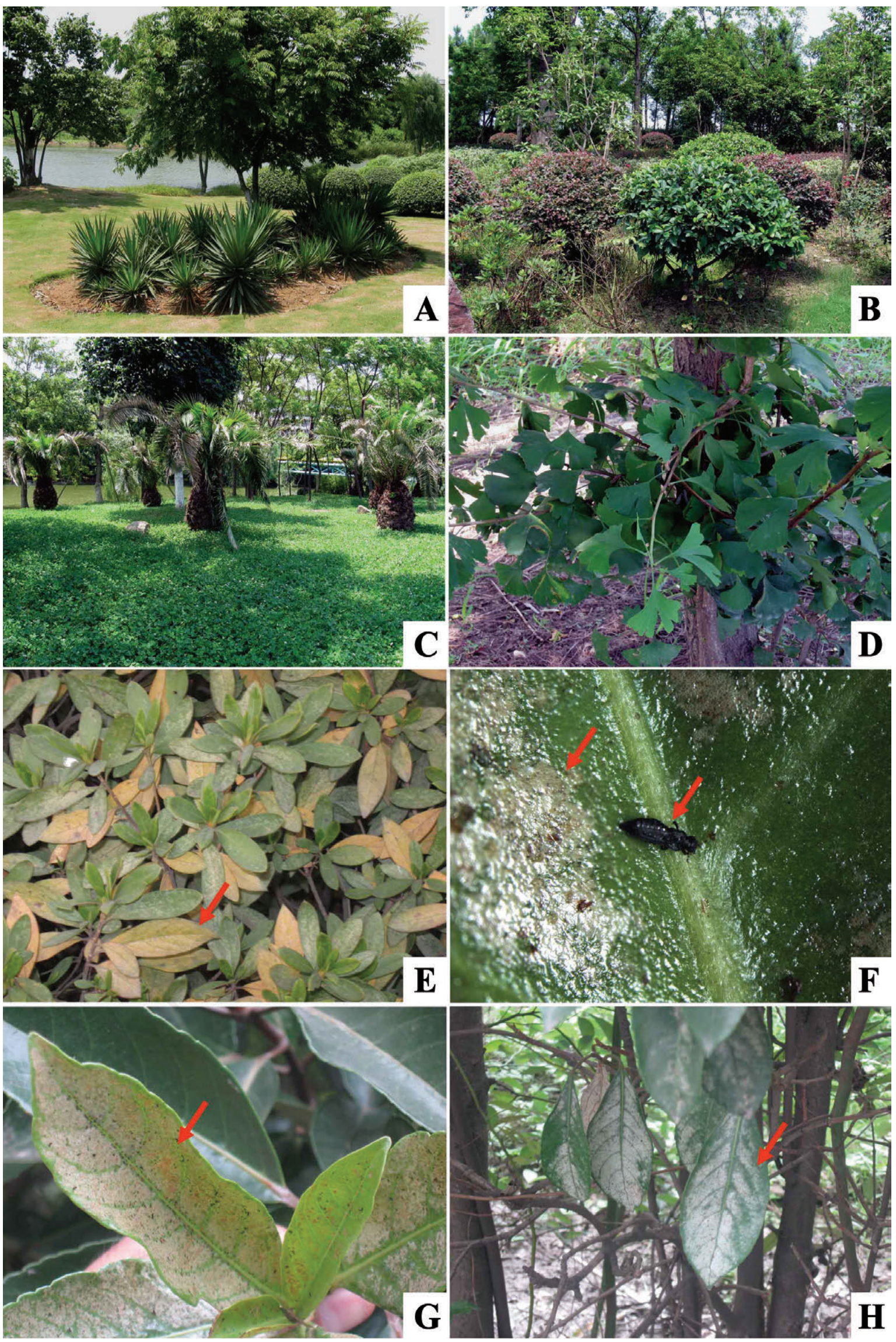

Figure 1. A-C) A view of some sites sampled in the urban environment of Hangzhou; D) leaves of the Gingko tree, infested by thrips; E-H) leaves damaged by Selenothrips rubrocinctus. 
florivorous, such as Frankliniella intonsa; a few of them, such as Selenothrips rubrocinctus and Scirtothrips dorsalis, are regarded as pests in this ecosystem, whereas Scolothrips and Aeolothrips species are predatory and feed on other small arthropods.

\section{Predatory thrips}

Three species, Aeolothrips fasciatus (Linnaeus), Scolothrips latipennis Priesner and Scolothrips takahashii Priesner, represent predators that play an important role in this ecosystem by feeding on other small arthropods. Among them, $S$. latipennis Priesner is a newly recorded species for China.

\section{Scolothrips latipennis Priesner (new record)}

Scolothrips latipennis Priesner, 1950: 54

MATERIAL EXAMINED. $6920^{\circ}$ (in ZJUH), CHINA: Huajiachi Campus at Zhejiang University, Hangzhou, Zhejiang Province, on Thuja sp. (Cupressaceae) (infested with tetranychid mites), 13.v.2011, Coll. M. Mirab-balou.

REMARKS (Figure 2A-D). The species of Scolothrips are predators of tetranychid mites and other small arthropods; they can be easily recognized by the presence of six pairs of very long setae on the pronotum and fore wings with dark bands (Masumoto, 2010). Presently, five species of this genus has been recorded from China (Mirab-balou et al., 2011a); S. lattipennis Priesner is here recorded for the first time among the fauna of China.

DISTRIBUTION. China (Zhejiang Province); Iran, Egypt, Crimea, Spain, Morocco, Canary Islands (zur Strassen, 2003), and Australia (Mound, 2011).

\section{Phytophagous thrips}

The remaining 23 species listed in Table 1 are phytophagous thrips that feed on different plant parts. The onion thrips, Thrips tabaci, is a widespread pest around the world. It is highly phytophagous and is also widely distributed on agricultural crops, fruit trees, flowers and other plants in Hangzhou. The chilli thrips or yellow tea thrips, Scirtothrips dorsalis, is another species distributed in China, and is a common pest in southern China, in particular in Guangdong, Guangxi, Hunan, Jiangxi, Fujian, Anhui and Yunnan provinces (Han, 1997; Mirab-balou et al., 2011a). Due to $S$. dorsalis' polyphagous behavior and very large host range, this species has the potential to cause significant economic damage. It has been reported as a serious pest of a diverse variety of commodities in several countries. This species is widely distributed in Hangzhou, especially on Ginkgo trees. Recently, another species of Scirtothrips, S. ginkgoe Mirab-balou \& Chen

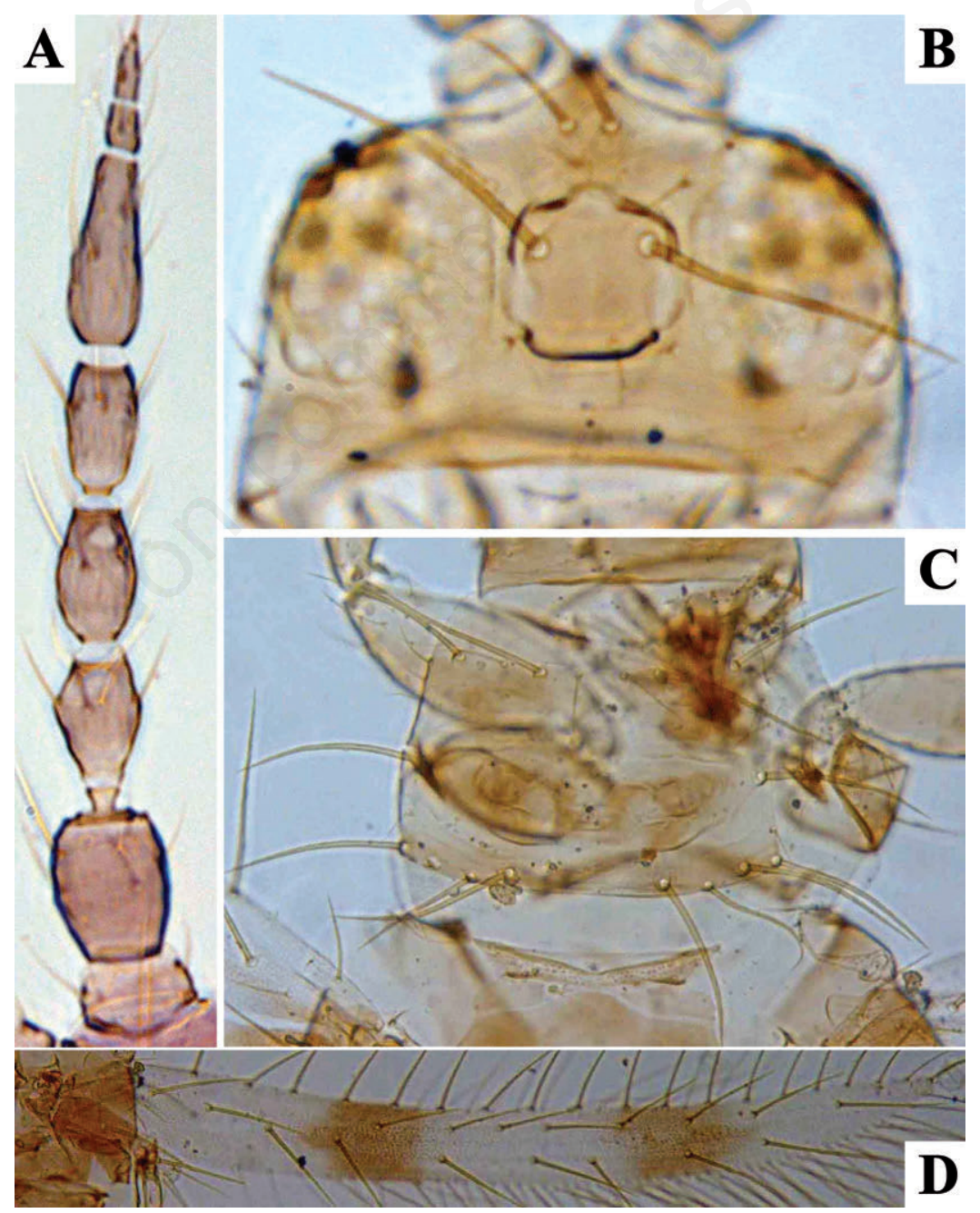

Figure 2. Scolothrips latipennis (\$): A) antenna, B) head, C) pronotum, D) fore wing. 
(2012b), was also recorded as a new pest in the urban environment of Hangzhou by Mirab-balou et al. (2012b). The red-banded thrips, Selenothrips rubrocinctus (Figure 1F), is polyphagous (Reyes, 1994) and recently noted to be widely distributed on different plants in Hangzhou. In this investigation, we observed a high level of damage (Figure 1E-H) caused by this species on plants near West Lake (Xihu), mostly in parks. Symptoms of red-banded thrips injury to plants result from feeding by the adults and/or larvae on the leaves and pods. On leaves, the feeding punctures cause the development of chlorotic spots and premature leaf drop, while on the pods, they cause brown patches that coalesce in severe infestations to form a dark brown, corky layer of dead cells that makes the determination of pod ripeness virtually impossible. Necrotic lesions are produced in the leaves and pods by adults and larvae, and in the flowers by adults. Small brown patches of excretory droplets, typical of thrips infestation, are an obvious means of identifying damage (Figure 1E-H).

Clover is cultivated in many regions in the environs of Hangzhou; consequently, Sericothrips houji (Chou and Feng) has become established on this plant at high populations (Mirab-balou et al., 2011b), which indicates a need for studies of its biology and potential control methods.

The Japanese Aralia, Fatsia japonica (Thunb.) Decne. and Planch. (Araliaceae), has been cultivated as a popular ornamental flower in many regions of Hangzhou, especially around West Lake (Xihu) and most roadsides, gardens and parks. Chaetanaphothrips orchidii (Moulton) is one of the important thrips species collected from flowers of Japanese Aralia, and is established on this plant within Hangzhou's landscape.

Aside from the above thrips species, other species such as Bagnalliella yuccae (Hind) are widely distributed on Yucca flowers (Mirab-balou et al., 2011a); Frankliniella intonsa (Trybom), Lefroyothrips lefroyi (Bagnall), Haplothrips spp. and Megalurothrips distalis (Karny) are also found on different varieties of plants (mostly on flowers), and Mycterothrips glycines (Okamoto) is found on leaves of trees in Hangzhou's urban environment.

\section{Discussion and conclusions}

Thysanoptera have been used as indicators of changes in agroecosytems (Lewis, 1973; Vasiliu-Oromulu, 2002), and as indicators of climatic changes (Vasiliu-Oromulu, 1995, 2002) and air pollution (Vasiliu-Oromulu et al., 2008, 2009). In this regard, some of the species listed here have the capability of serving as biomonitoring indices of polluted urban green spaces, such as Bagnalliella yuccae, Thrips tabaci, and Frankliniella intonsa.

\section{References}

CZEPIEL K., 2004 - Thrips (Thysanoptera, Insecta) collected in wooded areas of the city of Lublin (South-Eastern Poland). - Acta Phytopathol. Entomol. Hung. 39: 271-279.

HAN Y.F., 1997 - Thysanoptera. Economic insect fauna of China. vol. 55. - Editorial Committee of Fauna Sinica Chinese Academy of Sciences, Science Press, Beijing. [in Chinese].

KUCHARCZYK H., SECZKOWSKA K., 1990 - Thrips (Thysanoptera) of grond plant community (Tilio-Carpinetum) in the "Bachus" reserve (Lublin Upland). - Fragmenta Faunistica, Warszawa, 33: 349-360.

LEWIS T., 1973 - Thrips - their biology, ecology and economic importance. - Academic Press, London, New York: 349 pp.

MASUMOTO M., 2010 - Key to genera of the subfamily Thripinae (Thysanoptera: Thripidae) associated with Japanese plant quarantine. - Res. Bull. Plant Protect. Japan 46: 25-59.
MIRAB-BALOU M., CHEN X.X., 2010 - A new method for preparing and mounting thrips for microscopic examination. - J. Environ. Entomol. 32: 115-121.

MIRAB-BALOU M., CHEN X.X., 2011 - Iranian Thripinae with ctenidia laterally on the abdominal tergites (Thysanoptera: Thripidae). Natura Montenegrina: 10: 435-466.

MIRAB-BALOU M., TONG X.L., FENG J.N., CHEN X.X., 2011a - Thrips (Insecta: Thysanoptera) of China. - Check List J. Spec. Lists Distrib. 7: 720-744.

MIRAB-BALOU M., HU Q.L., FENG J.N., CHEN X.X., 2011b - A new species of Sericothripinae from China (Thysanoptera: Thripidae), with two new synonyms and one new record. - Zootaxa 3009: 55-61.

MIRAB-BALOU M., CHEN X.X., TONG X.L., 2012a - Thrips (Thysanoptera) species associated with Tea (Camellia sinensis) in Hangzhou, China. - Persian Gulf Crop Protect. 1: 28-34.

MIRAB-BALOU M., TONG X.L., CHEN X.X., 2012b - Scirtothrips ginkgoe sp. n. (Thysanoptera: Thripinae), a new species infesting Ginkgo biloba in eastern China. - J. Insect Sci. 12: 1-7.

MIRAB-BALOU M., YANG S.L., TONG X.L., 2013 - One new species, four new records and key to species of Hydatothrips (Thysanoptera: Thripidae) from China (including Taiwan). - Zootaxa 3641: 74-82.

MORITZ G., MOUND L.A., MORRIS D.C., GOLDARAZENA A., 2004 - Pest thrips of the world-visual and molecular identification of pest thrips. - CD, Centre for Biological Information Technology, Brisbane, Australia.

MOUND L.A., 1997 - Biological diversity. In: LEWIS T. (Ed.), Thrips as crop pests. CAB International, New York: 197-215.

MOUND L.A., 2005 - Thysanoptera: diversity and interactions. - Annu. Rev. Entomol. 50: 247-269.

MOUND L.A., 2011 - Species recognition in the genus Scolothrips (Thysanoptera, Thripidae, predators of leaf-feeding mites. Zootaxa 2797: 45-53.

MOUND L.A., MORRIS D.C., 2007 - The insect order Thysanoptera: classification versus systematics. - Zootaxa 1668: 395-411.

PRIESNER H., 1950 - Studies on the genus Scolothrips (Thysanoptera). - Bull. Soc. R. Entomol. Egypt. 34: 39-68.

REITZ S.R., GAO Y.L., LEI Z.R., 2011 - Thrips: pests of concern to China and the United States. - Agric. Sci. China 10: 867-892.

REYES C.P., 1994 - Thysanoptera (Hexapoda) of the Philippine Islands. - Raffles Bull. Zool. 42: 107-507.

ROBINSON W.H., 2005 - Handbook of urban insects and arachnids. Cambridge University Press, Cambridge: 481 pp.

RUDD H., VALA J., SCHAEFER V., 2002 - Importance of backyard habitat in a comprehensive biodiversity conservation strategy: a connectivity analysis of urban green spaces. - Restor. Ecol. 10: 368-375.

TONG X.L., LV Y.B., 2013 - Frankliniella cephalica (Crawford) (Thysanoptera, Thripidae), a newly recorded exotic invasive species in mainland China. - Chinese J. Appl. Entomol. 50: 496-499.

VASILIU-OROMULU L., 1995 - Population diversity of Thysanoptera in Romanian meadows. In: PARKER B.L., SKINNER M., LEWIS T. (Eds.), Thrips biology and management. - Plenum Press, New York, NATO ASI Series, Series A, Life Sciences, 276: 469-477.

VASILIU-OROMULU L., 2002 - The temporal and spatial dynamics of the thrips populations from the mountainous meadows. In: MARULLO R. and MOUND L. (Eds.), Thrips and tospoviruses. - Australian National Insect Collection, Canberra: 295-313.

VASILIU-OROMULU L., BARBUCEANU D., BIANU E., 2009 Thysanoptera capability for biomonitoring of urban polluted green spaces (Insecta: Thysanoptera). - Acta Entomol. Serb. 14: 185-194.

VASILIU-OROMULU L., JENSER G., BARBUCEANU D., 2008 Frankliniella intonsa (Trybom, 1895) a very sensitive bioindicator for air pollution. - Acta Phytopatol. Entomol. Hungarica 43: 401-408.

ZUR STRASSEN R., 2003 - Die terebranten Thysanopteren Europas und des Mittelmeer-Gebietes. - Die Tierwelt, Deutschlands, 74: 1-271. 